\title{
Effects of Nitrogen Deposition on Foliar Litter Decomposition and C, N, Ca, and P Dynamics in a Regenerating Forest
}

\author{
P. S. Munasinghe1, \# and H. M. L. K. Herath ${ }^{2}$ \\ ${ }^{1}$ Petroleum and Stable Isotope Geochemistry Laboratory \\ School of Geology and Geophysics, University of Oklahoma \\ Norman, OK, United States, 73071 \\ ${ }^{2}$ Department of Agribusiness Management \\ Faculty of Agriculture and Plantation Management \\ Wayamba University of Sri Lanka \\ Makandura, Gonawila (NWP), Sri Lanka \\ \#Corresponding Author \\ Tele: (01) 405514 7116; E-mail: sumudu73@yahoo.com
}

\begin{abstract}
Increases in atmospheric $N$ deposition over the past decades have raised concerns over nitrogen $(N)$ retention and carbon $(C)$ and nutrient cycling in forest ecosystems. Implications for $C$ and nutrient cycling are particularly acute in forests with periodic biomass harvesting. To understand how acid deposition interacts with harvesting removals to affect ecosystem $C, N$, calcium $(\mathrm{Ca})$ and phosphorus $(P)$ cycling and to assess the ability of dolomitic lime to counteract that effect, we followed decomposition and element dynamics in foliar litter at the Long-Term Soil Productivity (LTSP) study at the Fernow Experimental Forest (FEF) in West Virginia. $N$ deposition in the regenerating hardwood forest LTSP site is enhanced by periodic ammonium sulfate additions $(N+S)$. Other treatments include reference (ref) plot (no additions) and ammonium sulfate plus lime (lime). Fresh litter collected from the forest floor at the LTSP study had oak (48\%), yellow poplar (19\%), maple (14\%), magnolia (12\%), cherry (4\%), and birch (3\%). Fresh litter was collected from treatment plots in November. Air-dried litter was weighed, and placed in nylon litter bags. Litter bags were placed in treatment plots in March after the snow melt. Mass loss, $C, N, C a$ and $P$ dynamics were followed for 12 months. During the first 7 months of decomposition, $N$ and $P$ were immobilized in litter in all treatments. At 6 months, $N$ immobilization was significantly lower $(p=0.006)$ in the ammonium sulfate treatment $(117 \%)$ than in the reference $(128 \%)$ and lime (125\%) treatments. At 7 months, $N$ immobilization was significantly lower $(p=0.009)$ in the $N+S$ treatment $(104 \%)$ than in the reference $(113 \%)$ and in lime (115\%) treatment. After twelve months, there were significant differences among treatments for mass loss, $C, C a$, and $P$ dynamics. Remaining mass was highest in lime treatment (43\%) and it was significantly higher than the $N+S(39 \%)$ and
\end{abstract}


reference (37\%) treatments. Remaining $C$ was higher in both lime $(41 \%)$ and $N+S$ $(42 \%)$ treatments than in reference (36\%), and it was significantly different in ammonium sulfate treatment than in reference $(p=0.0337)$. Remaining $C a$ was significantly higher in ammonium sulfate treatment (42\%) than in reference (36\%) $(p=0.0051)$. Nitrogen mineralized at 12 months in all treatments, and the remaining $P$ in the $N+S$ treatment (107\%) was significantly higher than in the reference (83\%) and lime treatment (90\%). Increase in $N$ and $P$ contents during decomposition suggest that both $N$ and $P$ are limiting to microbial growth and forests. Decreasing $N$ immobilization and increasing $P$ immobilization during leaf litter decomposition in $N$ addition treatments indicate that atmospheric $N$ deposition may affect nutrient dynamics during litter decomposition and may have an impact on ecosystem scale $C$ cycling and forest productivity. Our results also showed that lime plays a significant role in decreasing litter decay, increasing $N$ immobilization and decreasing $P$ immobilization, which shows the potential of lime to counteract the effects of $N$ deposition.

KEYWORDS: Decomposition, Forest ecosystems, Nitrogen

\section{Introduction}

The northeastern USA receives the largest amounts of atmospheric $\mathrm{N}$ deposition in North America (Fenn et al., 1998). Annual $\mathrm{NO}_{3}{ }^{-}$deposition in precipitation in the Adirondack National Park in New York was reported in the range of 6.9 to $38.6 \mathrm{~kg}$ of nitrate- $\mathrm{N} \mathrm{ha}^{-1} \mathrm{yr}^{-1}$, while $\mathrm{SO}_{4}{ }^{2-}$ deposition in precipitation was reported in the range of 7.6 to $22.5 \mathrm{~kg}$ of sulfate-Sulfur $\mathrm{ha}^{-1} \mathrm{yr}^{-1}$ (Ito et al., 2002). In central Appalachia, the Fernow Experimental Forest (FEF) in West Virginia receives about $17 \mathrm{~kg}$ of $\mathrm{N} \mathrm{ha}^{-1} \mathrm{yr}^{-1}$ and about $20 \mathrm{~kg}$ of $\mathrm{S} \mathrm{ha}^{-1} \mathrm{yr}^{-1}$ through atmospheric deposition (Adams et al., 2000). The FEF also contains sites that are nearing or have reached $\mathrm{N}$ saturation (Gilliam et al., 1996; Peterjohn et al., 1996; Adams et al., 1997).

Nihlgard (1985) reported the potential of atmospheric $\mathrm{N}$ deposition to saturate biological demand and impact ecosystem processes. Two hypothetical views have been proposed with regard to $\mathrm{N}$ saturation. One was based on forest processes (Aber et al., 1989, 1998) and the other was based on seasonal changes in nitrate concentrations in surface waters (Stoddard, 1994). Both of these hypotheses consider $\mathrm{NO}_{3}{ }^{-}$dynamics as the main characteristic of $\mathrm{N}$ status of forests. The mobile nature of $\mathrm{NO}_{3}^{-}$leads to adverse effects under $\mathrm{N}$ saturation conditions and these effects include acidification of soil and water bodies, increased aluminum mobility and increased aluminum contents in streams, excessive cation leaching, and nutrient imbalances in trees (Vitousek et al., 1997; Aber et al., 1998; Fenn et al., 1998).

A long term $\mathrm{NO}_{3}{ }^{-}$increase in stream water has been observed at the FEF (Peterjohn et al., 1996). The possible chronic displacement of cations from the soil exchange sites could ultimately deplete the exchangeable pools of calcium and other base 
cations, which raises concerns about long-term soil productivity in impacted forests (Adams et al., 2004).

In addition to nutrient losses through leaching, timber harvesting removes a substantial amount of nutrients from a forest ecosystem. Nutrient removal is directly related to organic matter removal (Smith et al., 1986; Mann et al., 1988; Federer et al., 1989). Whole tree harvesting removes more biomass from the system and hence removes more nutrients than clear cutting (Adams et al., 2000). Adams et al. (2000) reported that harvesting could also lead to short-term acidification in the soil solution by increased $\mathrm{N}$ cycling and nitrification rates.

Nutrient replenishment in terrestrial ecosystems is dependent to a large extent on decomposition of plant litter (Knorr et al., 2005). For example, in natural perennial ecosystems a major portion of the plant $\mathrm{P}$ demand is provided by $\mathrm{P}$ cycling in organic residues (Halm et al., 1972; Miller et al., 1979; Attiwill, 1980). Climate, litter chemistry, external inputs of nitrogen and the microbial decomposer community interact to determine the rate of litter decomposition and nutrient dynamics (Knorr et al., 2005). The relationship between litter decomposition and external $\mathrm{N}$ inputs is complex (Knorr et al., 2005).

Some studies have reported accelerated decay rates in litter in response to increased external nitrogen inputs (Hunt et al., 1988; Carreiro et al., 2000; Hobbie, 2000; Hobbie and Vitousek, 2000). Many other studies, however reported either lowered decay rates (Magill and Aber, 1998; Carreiro et al., 2000) or no significant change (McClaugherty et al., 1987; Pastor et al., 1987; Hunt et al., 1988; Prescott, 1995; Bryant et al., 1998; Carreiro et al., 2000). The objectives of this study was to evaluate whether external $\mathrm{N}$ inputs have an effect on litter decomposition and on $\mathrm{C}$, $\mathrm{N}, \mathrm{Ca}$ and $\mathrm{P}$ dynamics in the forest floor of a regenerating hardwood forest and whether liming can reverse these effects.

\section{Materials and Methods}

\section{Study Site}

We conducted the experiment in the Long Term Soil Productivity (LTSP) Study located at the Fernow Experimental Forest (FEF) in Tucker County, West Virginia (latitude $39^{\circ} 04^{\prime} \mathrm{N}$, longitude $79^{\circ} 41^{\prime} \mathrm{W}$ ) on Fork Mountain (Adams et al., 2004). The site has a southeast aspect and the elevation ranges from $798 \mathrm{~m}$ to $847 \mathrm{~m}$. Land slope ranges from 15 to 31 percent (Adams et al., 2004). The LTSP experiment was established in 1996 with three objectives, to 1) characterize the productivity, diversity and biogeochemistry of a forest system under conditions of enhanced atmospheric deposition, 2) determine the response of the forest ecosystem to base cation removal, and 3) modify existing vegetation/nutrient/hydrologic models to describe and simulate forest changes due to base removals and acidic deposition (Adams et al., 2004). 
The LTSP experiment has four treatments replicated in four blocks at different slope positions: 1) Uncut and untreated control, 2) whole-tree harvesting, 3) wholetree harvesting plus ammonium sulfate additions, and 4) whole-tree harvesting plus ammonium sulfate and dolomitic lime addition. Each experimental plot is 0.2 ha in size with a $7.6 \mathrm{~m}$ wide buffer strip (Adams et al., 2004). For our study we used three treatments: 1) whole-tree harvesting (reference), 2) whole-tree harvest + ammonium sulfate $(\mathrm{N}+\mathrm{S})$ additions (ammonium sulfate), and 3) whole-tree harvest + additions of both ammonium sulfate and dolomite (lime). The uncut and untreated control was not used in our study because those trees are older than the trees in rest of the plots.

A total of 12 experimental plots (4 replicates per treatment) were used for this study. The ammonium sulfate treatment is designed to simulate acid deposition at twice the ambient rate in order to accelerate cation leaching from the soil. In the early 1980's, ambient atmospheric deposition rates of throughfall $\mathrm{N}$ and $\mathrm{S}$ in this region were $\sim 15$ and $17 \mathrm{~kg} \mathrm{ha}^{-1} \mathrm{yr}^{-1}$ respectively (Helvey and Kunkle, 1986), therefore $36 \mathrm{~kg} \mathrm{~N}$ and $40 \mathrm{~kg} \mathrm{~S}^{-1}$ are added annually with the ammonium sulfate treatment. Enhanced deposition is applied three times a year in March, July and November. In March and November $34 \mathrm{~kg}$ of ammonium sulfate is applied ha-1 $(7.1$ $\mathrm{kg} \mathrm{N} \mathrm{ha}{ }^{-1}$ and $8.1 \mathrm{~kg} \mathrm{~S} \mathrm{ha}^{-1}$ ), while in July $101 \mathrm{~kg}$ of ammonium sulfate is applied $\mathrm{ha}^{-1}\left(21.3 \mathrm{~kg} \mathrm{~N} \mathrm{ha}^{-1}\right.$ and $24.4 \mathrm{~kg} \mathrm{~S} \mathrm{ha}^{-1}$ ) (Adams et al., 2007). Stream water exports of $\mathrm{Ca}$ and $\mathrm{Mg}$ at the FEF for an untreated mature forested watershed (WS4) are about 11.25 and $5.83 \mathrm{~kg} \mathrm{ha}^{-1} \mathrm{yr}^{-1}$, respectively (Adams et al., 1997). Dolomitic lime is added every other year in March at a rate twice that of stream water export of $\mathrm{Ca}$ at the experimental site.

\section{Foliar Litter Collection and Litter Bag Preparation}

Foliar litter was collected separately from each treatment plot from the top litter layer in December, 2005. Leaves were separated by species from individual plots and were pooled by treatment into northern red oak (Quercus rubra), maple species, yellow poplar (Liriodendron tulipifera), magnolia species, sweet birch (Betula lenta), and cherry species. The maple speices contained a mix of red maple (Acer rubrum) and sugar maple (Acer saccharum). The magnolia species contained both fraser magnolia (Magnolia fraseri) and cucumber magnolia (Magnolia acuminata). The cherry species contained a mix of black cherry (Prunus serotina) and pin cherry (Prunus pennsylvanica).

From here on, we refer the above as maple, magnolia, and cherry groups. Leaves were allowed to air dry for 10 days. The proportion of each leaf litter species in the litter bags was decided by the proportion of each litter species to the total leaf litter weight collected from the treatment plots. Relative weight by species and treatment was reproduced in litter bags. Each litter bag contained $48 \%$ oak, $19 \%$ poplar, $14 \%$ maple group, $12 \%$ magnolia group, $4 \%$ cherry group, and 3\% sweet birch. Litter 
bags were made of nylon with $2 \mathrm{~mm}$ mesh size and dimensions of $25 \times 22 \mathrm{~cm}$. Approximately $10 \mathrm{~g}$ (total weight) of air-dried leaf litter was placed in each litter bag. Three sub-samples for each leaf species were oven-dried at $65^{\circ} \mathrm{C}$ for 48 hours to determine their oven-dry weights. The difference between oven-dry and air-dry weight was used to calculate litter moisture content. Oven-dry weights of litter in each litter bag were estimated using the moisture content of each litter type.

\section{Litter Bag Placement and Collections}

Litter collected from each treatment plot was allowed to decay in the same treatment plot, after the preparation of litter bags. Ten litter bags were placed in a random fashion in each experimental plot after snowmelt on March 15, 2006. Litter bags were placed on the mineral soil and held in place with landscape pins. Two bags were collected from each plot at 3, 6, 7, and 12 months after placement in the experiment site.

\section{Nutrient Analysis and Mass Loss Measurements}

After collection, litter bags were brought to the lab and manually cleaned of debris attached to the outer surface of the nylon bags. Leaf litter was sorted into species within one week of collection. Litter was dried in the oven for 48 hours at $65^{\circ} \mathrm{C}$ and weighed to the nearest hundredth gram. Mass loss over time $(w)$ was calculated using the following formula:

$$
w \frac{\left(W_{o}-W_{t}\right)}{W_{0}} \%
$$

$W_{t}=$ oven dry mass of litter remaining at time $\mathrm{t}$.

$W_{0}=$ initial oven dry mass of litter.

Litter decomposition rate/decay constant $(\mathrm{k})$ was calculated from the percentage of dry mass remaining using an exponential decay model (Olson, 1963):

$$
\begin{aligned}
& W_{t} / W_{0}=e^{-k t} \\
& k=\text { decay constant. }
\end{aligned}
$$

Oven-dried litter was ground separately by species and by treatment on a Wiley mill (60 mesh). The Willey mill was vacuum-cleaned between samples. Ground litter was re-dried, and 0.3 to 0.5 grams were weighed into tin capsules $(0.009 \times 0.005 \mathrm{~m})$, peletted, and analyzed for total C and N on a Carlo Erba NA 1500 NCS elemental analyzer with a Micro Dumas Combustion procedure. Approximately 0.2 grams of ground litter was weighed into digestion tubes and acid digested using $5 \mathrm{ml}$ of 
concentrated nitric acid and $30 \%$ hydrogen peroxide at $125^{\circ} \mathrm{C}$ on a digestion block. The litter samples were digested for approximately 5 to 7 hours until they appeared colorless. The digested volume was brought up to $75 \mathrm{~mL}$ with deionized water and then filtered using $0.45 \mu \mathrm{m}$ nylon filters.

Aliquots from the filtrate were used to measure total Ca using a Varian Spectra 220 atomic absorption spectrophotometer at $225 \mathrm{~nm}$ wavelength using nitrous oxide/acetylene gas. For total P measurement, $0.2 \mathrm{~mL}$ of the aliquot was mixed with $1.8 \mathrm{~mL}$ of Ammonium molybdate and allowed to sit for 5 minutes for the color development. Total $\mathrm{P}$ was measured at $550 \mathrm{~nm}$ wavelength using a Shimadzu 160U spectrophotometer (Taussky and Shorr, 1953). Initial nutrient concentrations $(\mathrm{C}, \mathrm{N}, \mathrm{Ca}$, and $\mathrm{P})$, were measured for each group of species.

The nutrient concentrations for each litter bag (c) and remaining nutrient contents (r) were estimated by the following formula:

$c=\frac{\sum\left(W_{t} * E_{t}\right)}{\sum W_{t}} \%$

$W_{t}=$ oven dry weights of oak, maple, poplar, magnolia, cherry, and birch at a given time

$E_{t}=$ elemental concentrations of $\mathrm{C}, \mathrm{N}, \mathrm{Ca}$, or $\mathrm{P}$ in oak, maple, poplar, magnolia, cherry and birch at a given time.

Remaining percent (r) of $\mathrm{C}, \mathrm{N}, \mathrm{Ca}$, or $\mathrm{P}$ contents were estimated using the following equation:

$r=\frac{\sum\left(W_{t} * E_{t}\right)}{\sum\left(W_{0} * E_{0}\right)} \%$

$E_{0}=$ initial elemental concentrations of $\mathrm{C}, \mathrm{N}, \mathrm{Ca}$, or $\mathrm{P}$ in oak, maple, poplar, magnolia, cherry, and birch.

\section{Statistical Analysis}

Statistical analyses were conducted by three-way ANOVA using SAS software (SAS). The main effects were treatment (reference, ammonium sulfate, and lime), block (1, 2, 3, and 4) and, sampling time (3, 6, 7, and 12 months). The data analysis was carried out under the assumption that the distribution of measured variables would behave normal. The initial nutrient concentrations $(\mathrm{C}, \mathrm{N}, \mathrm{Ca}$, and $\mathrm{P})$ and $\mathrm{C}$ :nutrient ratios $(\mathrm{C}: \mathrm{N}, \mathrm{C}: \mathrm{Ca}$, and $\mathrm{C}: \mathrm{P})$ were statistically analyzed by one-way ANOVA considering only the treatment effects. The main effects were considered significant at alpha $\leq 0.05$. Mean separation was performed using Turkey's test. 


\section{Results}

\section{Litter Characteristics}

\section{Initial Litter Characteristics}

Initial litter nutrient concentrations $(\mathrm{C}, \mathrm{N}, \mathrm{Ca}$ and $\mathrm{P})$ and $\mathrm{C}$ :nutrient ratios $(\mathrm{C}: \mathrm{N}$, $\mathrm{C}: \mathrm{Ca}$, and $\mathrm{C}: \mathrm{P}$ ) did not significantly differ among treatments (Table 1). However, the $\mathrm{N}$ concentration was highest in the ammonium sulfate treatment $(1.21 \%)$ and lowest in the reference $(1.08 \%)$. Also, litter Ca concentration was highest in the lime treatment $(1.27 \%)$ and lowest in the ammonium sulfate treatment $(1.06 \%)$.

Table 1: Initial nutrient concentrations and $C$ :nutrient ratios in litter for reference, lime, and ammonium sulfate treatment plots $(\mathrm{C}, \mathrm{N}$, and $\mathrm{Ca}$ in $\%$ basis and $P$ in $\mathrm{mg} / \mathrm{kg}$ )

\begin{tabular}{cccccccc}
\hline Treatments & $\mathbf{C}$ & $\mathbf{N}$ & $\mathbf{C a}$ & $\mathbf{P}$ & $\mathbf{C : N}$ & $\mathbf{C : C a}$ & $\mathbf{C : P}$ \\
\hline Reference & 48.5 & 1.08 & 1.25 & 526 & 44.9 & 38.8 & 921 \\
Lime & 48.5 & 1.14 & 1.27 & 511 & 42.4 & 38.1 & 953 \\
$\begin{array}{c}\text { Ammonium } \\
\text { sulfate }\end{array}$ & 48.9 & 1.21 & 1.06 & 525 & 40.5 & 46.5 & 933 \\
\hline
\end{tabular}

$\dagger$ None of the above parameters are significantly different among treatments

\section{Litter Characteristics at 12 Months}

Even after 12 months of decomposition, litters in the three treatments were not significantly different with respect to $\mathrm{C}: \mathrm{N}, \mathrm{C}: \mathrm{Ca}$, and $\mathrm{C}: \mathrm{P}$ ratios. Litter nutrient concentrations $(\mathrm{C}, \mathrm{N}, \mathrm{Ca}$ and $\mathrm{P})$ did not significantly differ among treatments (Table 2).

Table 2: Nutrient concentrations and $\mathrm{C}$ :nutrient ratios in litter at 12 months in reference, lime and ammonium sulfate treatment plots $(\mathrm{C}, \mathrm{N}$, and $\mathrm{Ca}$ in \% basis and $P$ in $\mathrm{mg} / \mathrm{kg}$ )

\begin{tabular}{llllllll}
\hline Treatments & $\mathbf{C}$ & $\mathbf{N}$ & $\mathbf{C a}$ & $\mathbf{P}$ & $\mathbf{C : N}$ & $\mathbf{C : C a}$ & $\mathbf{C : P}$ \\
\hline Reference & 46.6 & 2.09 & 1.29 & 940 & 21.5 & 35.2 & 505 \\
Lime & 47.7 & 2.21 & 1.37 & 927 & 21.6 & 41.1 & 519 \\
Ammonium sulfate & 47.1 & 2.38 & 1.12 & 881 & 20.6 & 42.5 & 538 \\
\hline
\end{tabular}

$\uparrow$ None of the above parameters are significantly different among treatments 


\section{ANOVA for the Litter Characteristics at 12 Month}

ANOVA table for the ambient litter mix mass loss and nutrient dynamics data was significant for the treatment as well as for the treatment and time interaction. Block effect was not significant (Table 3).

Table 3: ANOVA table for study 1

\begin{tabular}{ccccc}
\hline Sources & DF & SS & F value & Pr $>$ F \\
\hline Treatment & 2 & 0.90 & 14.66 & $<0.0001$ \\
Block & 3 & 0.92 & 2.05 & 0.1259 \\
Treatment x Time & 9 & 1.00 & 82.20 & $<0.0001$ \\
\hline
\end{tabular}

$\uparrow D F=$ degrees of freedom, $S S=$ sums of squares

\section{Treatment Effects on Litter Decomposition/Mass Loss Dynamics}

There were no significant differences among treatments for mass loss for the first six months. (Figure 1). By 12 months, however, remaining litter mass was significantly higher in the lime treatment $(43 \%)$ than in ammonium sulfate $(39 \%)$ and reference $(37 \%)$ treatments. At 12 months, lime treatment showed a significantly lower decomposition rate $(\mathrm{k}=0.823)$ than in reference $(\mathrm{k}=0.989)$ and ammonium sulfate $(\mathrm{k}=0.926)$ treatments $(\mathrm{p}=0.005)$.

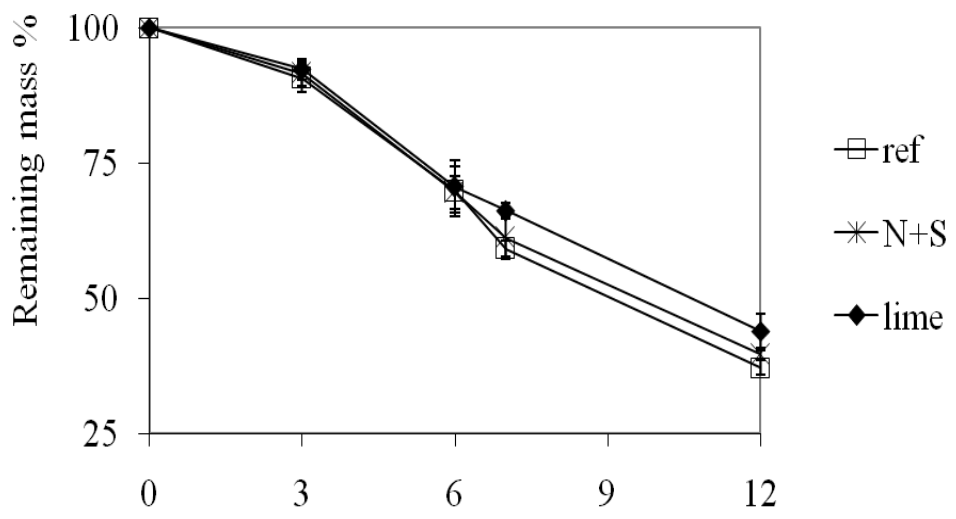

Time (month)

Figure 1: Remaining mass percentage in leaf litter in reference (ref), lime, and ammonium sulfate $(\mathrm{N}+\mathrm{S})$ treatments over time 


\section{Litter C Dynamics}

There were no significant differences among treatments for remaining $\mathrm{C}$ for the first 7 months (Figure 2). However, at 12 months, remaining $\mathrm{C}$ was significantly different $(\mathrm{p}=0.028)$ among treatments and it was significantly higher in ammonium sulfate treatment $(42 \%)$ than in the reference $(36 \%)$ treatment $(\mathrm{p}=0.034)$.

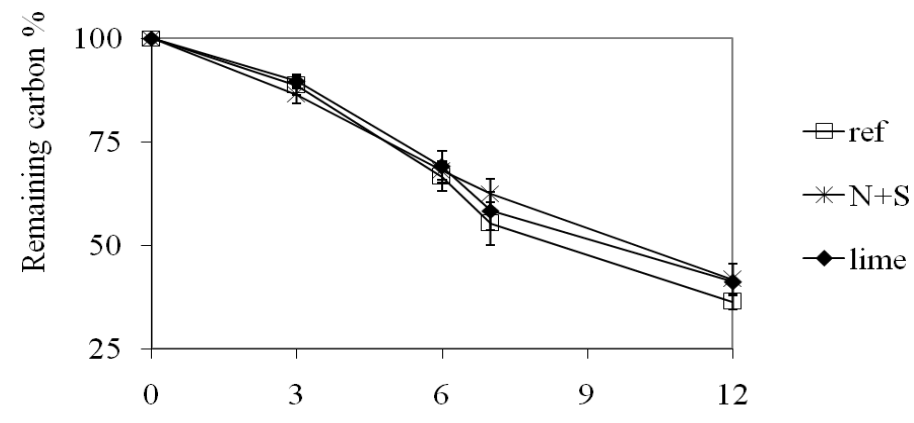

Time (month)

Figure 2: Remaining carbon percentage in leaf litter in reference (ref), lime, and ammonium sulfate $(\mathrm{N}+\mathrm{S})$ treatments over time

\section{Litter N Dynamics}

The peak for $\mathrm{N}$ immobilization was observed at 6 months when the remaining $\mathrm{N}$ content was 122, 119 and $111 \%$ in the reference, lime and ammonium sulfate treatments, respectively (Figure 3).

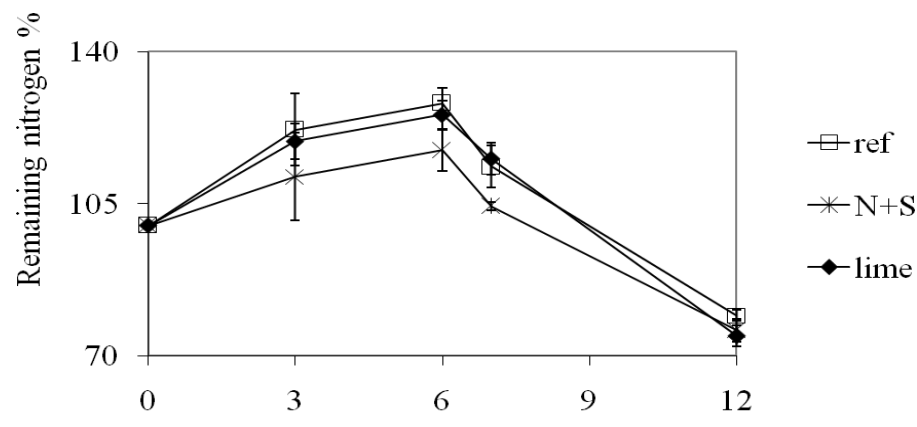

Time (month)

Figure 3: Remaining nitrogen percentage in leaf litter in the reference (ref), lime, and ammonium sulfate $(\mathrm{N}+\mathrm{S})$ treatments over time 
At both $6(\mathrm{p}=0.006)$ and 7 months $(\mathrm{p}=0.009)$, ammonium sulfate had significantly lower content of remaining $\mathrm{N}$ than the reference and lime treatments. In the first seven months, all litter exhibited net $\mathrm{N}$ immobilization irrespective of the treatment. At 7 months, remaining $\mathrm{N}$ content was 115, 113 and 104\% in lime, reference, and ammonium sulfate treatments, respectively. At 12 months, litter in all treatments showed net nitrogen mineralization and the remaining $\mathrm{N}$ content was 79,75 , and $74 \%$ in the reference, ammonium sulfate, and lime treatments, respectively.

\section{Treatment Effects on Litter Ca Dynamics}

Ca was mineralized in all treatments during the 12 months of decomposition (Figure 4). At 12 months, remaining calcium was $36 \%, 39 \%$, and $42 \%$ in the reference, lime, and ammonium sulfate treatments, respectively. Remaining $\mathrm{Ca}$ in the reference and ammonium sulfate treatment was significantly different $(\mathrm{p}=0.0051)$.

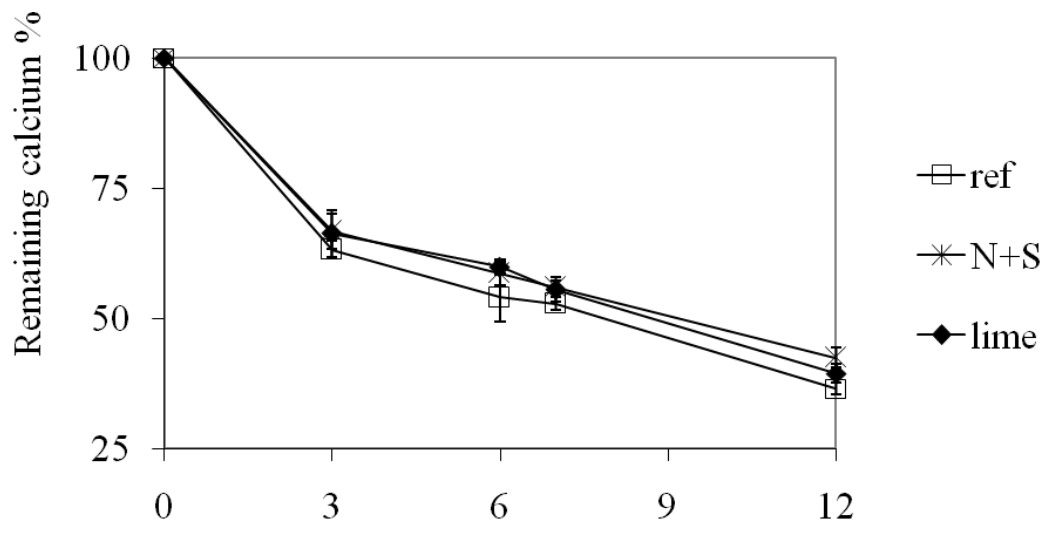

Time (month)

Figure 4: Remaining calcium percentage in leaf litter in reference (ref), lime, and ammonium sulfate $(\mathrm{N}+\mathrm{S})$ treatments over time

\section{Treatment Effects on Litter P Dynamics}

During the first 7 months, $\mathrm{P}$ was immobilized in all treatments. The peak for $\mathrm{P}$ immobilization was observed after 3 months of decomposition (Figure 5). At that time, remaining $\mathrm{P}$ was greater in the lime treatment $(175 \%)$ than in the reference $(160 \%)$, and ammonium sulfate treatments $(128 \%)$. There was a highly significant $(\mathrm{p}=0.0001)$ treatment effect on the remaining $\mathrm{P}$ at 12 months. Litter in the ammonium sulfate treatment had a significantly higher remaining P $(107 \%)$ than in the reference $(83 \%)$, and lime $(90 \%)$ treatments. Throughout the decomposition process (except for $3^{\text {rd }}$ month observation), remaining $\mathrm{P}$ was always higher in the $\mathrm{N}+\mathrm{S}$ and lime treatments than in the reference litter (Figure 5), showing that even after 12 months, litter in ammonium sulfate treatment was undergoing net $\mathrm{P}$ 
immobilization whereas litters in the reference, and lime treatments were undergoing net $\mathrm{P}$ mineralization. The switch from net $\mathrm{P}$ immobilization to net mineralization in the reference and lime treatment litter occurred somewhere between 7 and 12 months.

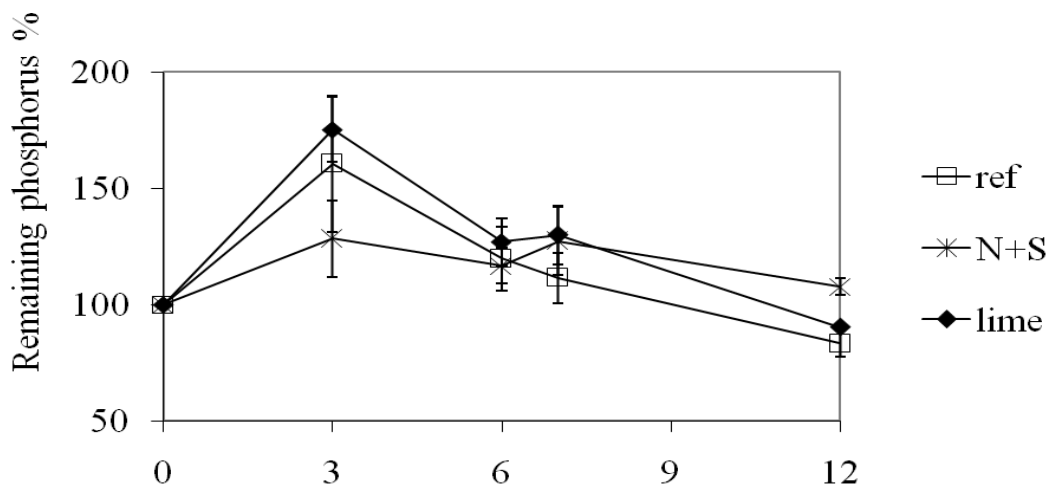

Time (month)

Figure 5: Remaining phosphorus percentage in leaf litter in reference (ref), lime, and ammonium sulfate $(\mathrm{N}+\mathrm{S})$ treatments over time

\section{Discussion}

\section{Litter Decomposition / Mass Loss Dynamics}

During the course of decomposition, litter in the lime treatment showed a lower decomposition rate compared to litters in the reference and ammonium sulfate treatments. At 7 months, remaining mass was significantly higher in lime treatment $(66 \%)$ than in the reference $(59 \%)(\mathrm{p}=0.020)$. At 12 months, remaining mass was significantly higher in lime treatment $(43 \%)$ than in the reference $(37 \%)$ and ammonium sulfate treatment (39\%), suggesting that lime may have an effect on suppressing litter decomposition $(\mathrm{p}=0.006)$.

Application of lime to forest ecosystems has produced contradictory results, either increasing (Marschner and Wilczynsh, 1991; Baath et al., 1995) or decreasing (Romkens et al., 1996) rates of decomposition. Romkens et al. (1996) reported that organic matter is stabilized by the $\mathrm{Ca}^{2+}$ ions present in lime. Therefore, lower rates of litter mass loss observed in our lime treatment could have been due to organic matter stabilization by $\mathrm{Ca}^{2+}$ ions present in lime.

Although the decomposition rates in ammonium sulfate and in the reference were not statistically significant, mass loss was always lower in the ammonium sulfate treatment than in the reference. Lower decomposition rates due to ammonium sulfate additions were reported by Adams and Angradi (1996). They carried out a 
litter decomposition study at a nearby watershed in the FEF where ammonium sulfate had been added in the same amount used in this experiment. They observed lower decomposition rates in yellow-poplar, black birch, and black cherry in the treated watershed (WS3) than in the reference watershed (WS7).

Many other studies have also reported lowered decay rates (Magill and Aber, 1998; Carreiro et al., 2000). However some studies have reported accelerated decay rates in litter in response to increased external nitrogen inputs (Hunt et al., 1988; Carreiro et al., 2000; Hobbie, 2000; Hobbie and Vitousek, 2000) or no significant change (McClaugherty et al., 1987; Pastor et al., 1987; Hunt et al., 1988; Prescott, 1995; Bryant et al., 1998; Carreiro et al., 2000). Generally, high doses of external nitrogen accelerate decomposition when plant tissues have low contents of lignin and other recalcitrant compounds, but decelerate decomposition rate when high lignin contents are present (Berg, 1986; Fog, 1988; Berg and Matzner, 1997).

Additions of $\mathrm{N}$ may inhibit the decomposition of lignin either by suppressing the synthesis of lignolytic enzymes or by influencing the formation of additional recalcitrant compounds, which are highly resistant to biological degradation (Keyser et al., 1978; Berg, 1986; Fog, 1988; Berg and Ekbohm, 1991; Berg and Matzner, 1997). Ammonium can suppress the activity of white rot fungi because high levels of $\mathrm{NH}_{4}{ }^{+}$inhibits their lignolytic enzymes (Berg, 1986; Fog, 1988).

In our experiment, $48 \%$ of each litter bag contained northern red oak. Oak leaves are highly lignified (Carreiro et al., 2000) and we assume that higher lignin content would have resulted in the observed lower decomposition in the treatment litter. We were not able to find any additional reports describing the role of lime on suppressing litter decomposition other than the explanation by Romkens et al. (1996). Other than litter quality, the degree and length of litter decomposition is also influenced by the application rate and the type of fertilizer applied, the amount of atmospheric $\mathrm{N}$ deposition, and the length of time which litter mass loss was measured (Knorr et al., 2005).

Litter in the reference plots did not get any additional $\mathrm{N}$ other than the $\mathrm{N}$ input from ambient atmospheric deposition. The annual decay rate constants (k) were 0.989 , 0.926 and 0.823 for litter in the reference, ammonium sulfate, and lime treatments, respectively. Similar annual k values were reported by Adams and Angradi (1996) to be $0.893,0.890$, and 1.442 for black birch, yellow poplar, and black cherry in a litter decomposition study in WS3 at the FEF. Based on the results observed in our decomposition experiment, we could assume that the additional $\mathrm{N}$ and its effects on the litter carbon quality (mainly lignin) and also the role of $\mathrm{Ca}^{2+}$ ions would have been the determining factors for the treatment differences observed in litter decomposition rate/mass loss over time. 


\section{Litter C Dynamics}

During the process of decomposition, carbon becomes oxidized and lost as $\mathrm{CO}_{2}$ and dissolved organic carbon (DOC); some $\mathrm{C}$ may also be lost as organic matter that becomes fragmented and lost from the bag. These losses account for the decrease in the mass of litter. Therefore, the dynamics of $\mathrm{C}$ remaining in litter were similar to the dynamics of mass loss (decomposition) observed. At 3 months, litter $\mathrm{C}$ loss was greater in the ammonium sulfate treatment than in lime treatment and reference, but at 7 months there were no statistically significant differences among the treatments for litter carbon contents. At 12 months, more $\mathrm{C}$ remained in ammonium sulfate and lime treatments than in the reference.

Fog (1988) explained that the response of organic matter to higher $\mathrm{N}$ concentrations may change through time, and litter mass loss and microbial respiration could increase at first, but the long-term responses could decrease. Higher remaining $\mathrm{C}$ observed in our study in both ammonium sulfate and lime treatments was probably due to the effect of excess $\mathrm{N}$ from ammonium sulfate and lime treatments on the decay of the residual litter with more recalcitrant compounds. Our findings are further supported by Fog (1988) who experimented on seven forested sites in western Washington and Oregon and reported that long-term elevated $\mathrm{N}$ can increase soil organic matter stability.

\section{Litter N Dynamics}

Net immobilization was the dominant $\mathrm{N}$ process in litter irrespective of the treatment for 6 of the 12 months of decomposition. Adams and Angradi (1996) reported similar results of $\mathrm{N}$ immobilization in a watershed acidification study at the FEF. Nitrogen immobilization or an increase in $\mathrm{N}$ with time over initial $\mathrm{N}$ content during litter decomposition is a wide-spread phenomenon observed for different litter types and forests (Gosz et al., 1973; Berg and Ekbohm, 1991; Piatek and Allen, 2001; Bates et al., 2007).

The occurrence of $\mathrm{N}$ immobilization is indicative of $\mathrm{N}$ limitation to decomposers and also perhaps for forest productivity. At the end of 12 months, litter of all three treatments in our study showed net nitrogen mineralization. The switch between $\mathrm{N}$ immobilization and mineralization occurred sometime between 6 and 7 months of decomposition. A lower remaining $\mathrm{N}$ content in the ammonium sulfate treatment indicated that there was a lower level of $\mathrm{N}$ retention in the litter, which suggest that doubling the rate of ambient atmospheric acid deposition lowers the rate of $\mathrm{N}$ immobilization during litter decomposition. A reduced rate of $\mathrm{N}$ immobilization under simulated atmospheric acid deposition could result in more $\mathrm{N}$ leaching from the forest floor, which could end up in surface water unless retained by some other mechanism (e.g. plant uptake). Hobbie (2000) reported that fertilization with $\mathrm{N}$ increased $\mathrm{N}$ immobilization in high lignin litter. 
We did not measure lignin in our experiment. Therefore, we are unable to relate $\mathrm{N}$ dynamics to lignin contents in the litter. The source of $\mathrm{N}$ for immobilization in our study could be from the soil, ammonium sulfate fertilizer applied on the plots, throughfall, or from $\mathrm{N}$ fixation by microorganisms in the forest floor. In our litter study, net $\mathrm{N}$ mineralization began somewhere between 6 (September) and 7 (October) months of decomposition, when the tree nutrient use shuts down at the end of the growing season. Therefore, the $\mathrm{N}$ that mineralized from litter during the above period may have leached in to streams or ground water.

\section{Litter Ca Dynamics}

In all three treatments, calcium was mineralized (decreased in content over original) during the 12 months of decomposition (Figure 4). Adams and Angradi (1996) reported an initial immobilization of $\mathrm{Ca}$ in black birch and black cherry litter and later mineralization. Initial $\mathrm{Ca}$ concentrations in those litters were $0.85,1.29,1.15$ and $1.06 \%$ for black birch, poplar, black cherry, and red maple leaf litter, respectively (Adams and Angradi, 1996).

In comparison, the initial Ca concentrations in our study were $1.25,1.27$, and $1.06 \%$ in reference, lime, and ammonium sulfate treatments. Although the initial $\mathrm{Ca}$ concentrations were approximately similar in the above two studies, Ca mineralization rates were different. By the end of the first year of the individual decomposition of black birch, black cherry, yellow poplar, and red maple, litters had approximately 20\% of remaining Ca (Adams and Angradi, 1996), while treatment litter had 2 times more remaining calcium (40\%) in our study.

The litter mix we studied contained $48 \%$ red oak. We assume that the presence of highly lignified red oak in our litter mix resulted in the above difference in the remaining $\mathrm{Ca}$ content. At 12 months, remaining $\mathrm{Ca}$ in the reference (36\%) was significantly lower than in the ammonium sulfate treatment (42\%), again suggesting that excess $\mathrm{N}$ may influence lower decomposition rates in highly lignified litter and consequently reducing $\mathrm{Ca}$ mineralization.

\section{Litter P Dynamics}

In our study, net $\mathrm{P}$ immobilization was greater than net $\mathrm{N}$ immobilization. Higher net $\mathrm{P}$ immobilization than $\mathrm{N}$ immobilization was also reported in Eucalyptus obliqua (Baker and Attiwill, 1985) and in Eucalyptus diversicolor forests (O’Connell, 1988). Adams and Angradi (1996) reported an early P increase during the first 6 months of decomposition in red maple, black birch, and cherry litter due to net $\mathrm{P}$ immobilization in another study at the FEF. In our study, $\mathrm{P}$ was immobilized in all treatments during the first 3 months (Figure 5). The switch between $\mathrm{P}$ immobilization and mineralization occurred sometime between 3 and 6 months of decomposition. 


\section{Conclusions}

Our results suggest that simulated atmospheric acid deposition at twice the ambient rates may alter litter nutrient dynamics by altering $\mathrm{N}$ and $\mathrm{P}$ cycling in a 10 -year old regenerating forest. This effect was observed 10 years after the treatment started; no earlier data are available. Based on 12 months data, lime treatment appears to alleviate the effects of atmospheric $\mathrm{N}$ deposition by increasing $\mathrm{N}$ immobilization, $\mathrm{Ca}$ mineralization, and by lowering $\mathrm{P}$ immobilization during leaf litter decomposition. Immobilization of $\mathrm{N}$ and $\mathrm{P}$ during litter decomposition suggests that $\mathrm{N}$ and $\mathrm{P}$ are both limiting for microbial growth and forests. Most temperate forests are $\mathrm{N}$ and $\mathrm{P}$ limited and atmospheric $\mathrm{N}$ deposition could further aggravate the extent of P limitation (Gress et al., 2007). Our results also suggest that if atmospheric acid deposition could suppress litter decomposition, long-term elevated $\mathrm{N}$ may have a substantial impact on $\mathrm{C}$ sequestration and eventually on the global $\mathrm{C}$ budget.

\section{References}

Aber, J., K. J. Nadelhoffer, P. Steudler and J. M. Melill0 (1989). "Nitrogen saturation in northern forest ecosystems" BioScience, 39: 378-386.

Aber, J., W. McDowell, K. Nadelhoffer, A. Magill, G. Berntson, M. Kamakea, S. McNulty, W. Currie, L. Rustad and I. Fernandez (1998). "Nitrogen saturation in temperate forest ecosystems" BioScience, 48: 921-934.

Adams, M. B. and T. R. Angradi (1996). "Decomposition and nutrient dynamics of hardwood leaf litter in the Fernow Whole-Watershed Acidification Experiment" For. Ecol. Manage., 83: 61-69.

Adams, M. B., T. R. Angradi and J. N Kochenderfer (1997). "Stream water and soil responses to five years of nitrogen and sulfur additions at the Fernow Experimental Forest, West Virginia" For. Ecol. Manage., 95: 79-91.

Adams, M. B., J. A. Burger, A. B. Jenkins and L. Zelazny (2000). "Impact of harvesting and atmospheric pollution on nutrient depletion of eastern US hardwood forests" For. Ecol. Manage., 138: 301-319.

Adams, M. B., J. Burger, L. Zelazny and J. Baumgras (2004). "Description of the Fork mountain long-term soil productivity study: site characterization". USDA For. Serv. Northeastern Research Station Gen. Tech. Rep. NE-323, 19.

Adams, M. B., J. N. Kochenderfer and P. J. Edwards (2007). "The Fernow Watershed Acidification Study: Ecosystem Acidification, Nitrogen Saturation and Base Cation Leaching" Water Air Soil Pollut., 7: 267-273.

Attiwill, P. M. (1980). "Nutrient cycling in a Eucalyptus oblique (L' Herit.) forest. IV Nutrient uptake and nutrient return" Aust. J. Bot., 28: 199-222. 
Baath, E., A. Frostegtd, T. Pennanen and H. Fritze (1995). "Microbial community structure and $\mathrm{pH}$ response in relation to soil organic matter quality in wood-ash fertilized, clear-cut or burned coniferous forest soils" Soil Biol. Biochem, 27: 229-240.

Baker, T. G. and P. M. Attiwill (1985). "Loss of organic matter and elements from decomposing litter of Eucalyptus oblique L' Herit. and Pinus radiata D. Don. Australian" For. Res., 15: 309-319.

Bates, J. D., T. S. Svejcar and R. F. Miller (2007). "Litter decomposition in cut and uncut western juniper woodlands" J. Arid Environ., 70: 222-236.

Berg, B., and E. Matzner (1997). "Effect of N deposition on decomposition of plant litter and soil organic matter in forest systems" Environ. Rev., 5:1-25.

Berg, B. (1986). "Nutrient release from litter and humus in coniferous forest soils-a mini review Scandinavian J." For. Res., 1: 359-369.

Berg, B., and G. Ekbohm (1991). "Litter mass-loss rates and decomposition patterns in some needle and leaf litter types. Long-term decomposition in a Scots pine forest." Can. J. Bot., 69: 1449-1456.

Bryant, D. M., E. A. Holland, T. R. Seastedt and M. D. Walker (1998). "Analysis of litter decomposition in an alpine tundra" Can. J. Bot., 76: 1295-1304.

Carreiro, M. M., R. L. Sinsabaugh, D. A. Repert and D. F. Parkhurst (2000). "Microbial enzyme shifts explain litter decay responses to simulated $\mathrm{N}$ deposition" Ecology, 81: 2359-2365.

Chapman, K., J. B. Whittaker and O. W. Heal (1988). "Metabolic and faunal activity in litter of tree mixtures compared with pure stands" Agric. Ecosyst. Environ. 24: 33-40.

Federer, C. A., J. W. Hornbeck, L. M. Tritton, C. W. Martin, R. S. Pierce and C. T. Smith (1989). "Long-term depletion of calcium and other nutrients in eastern US forests" Environ. Manage. 13: 593-601.

Fenn, M. E., M. A. Poth, J. D. Aber, J. S. Baron, B. T. Bormann, D. W. Johnson, A. D. Lemly, S. G. McNulty, D. F. Ryan and R. Stottlemeyer (1998). "Nitrogen excess in North American ecosystems: Predisposing factors, ecosystem responses, and management strategies" Ecol. Appl., 8: 706-733.

Fog, K. (1988). "The effect of added $\mathrm{N}$ on the rate of decomposition of organic matter" Biological Review, 63: 433-462.

Fyles, J. W. and I. H. Fyles (1993). "Interaction of Douglas-fir with red alder and salal foliage litter during decomposition" Can. J. For. Res., 23: 358-361.

Gilliam, F. S., M. B. Adams and B. M. Yurish (1996). "Ecosystem nutrient responses to chronic nitrogen inputs at Fernow Experimental Forest, West Virginia" Can. J. For. Res., 16: 196-205. 
Gosz, J. R., G. E. Liken and F. H. Borman (1973). "Nutrient release from decomposing leaf and branch litter in the Hubbard Brook Forest, New Hampshire" Ecological Monographs, 43: 173-191.

Gress, S. E., T. D. Nichols, C. C. Northcraft and W. T. Peterjohn (2007). "Nutrient limitation in soils exhibiting differing nitrogen availabilities: What lies beyond nitrogen saturation?" Ecology, 88: 119-130.

Halm, B. J., J. W. B. Stewart and R. L. Halstead (1972). "The phosphorus cycle in a native grassland ecosystem" In: Isotopes and radiation in soil-plant relationships, including forestry. Vienna: International Atomic Energy Agency, 571-586.

Helvey, J. D. and S. H. Kunkle (1986). "Input-out budgets of selected nutrients on an experimental watershed near Parsons, West Virginia". Res. Pap. NE-584. Broomall, PA: USDA For. Serv. Northeastern Forest Experiment Station. 7p.

Hobbie, S. E. (2000). "Interactions between litter lignin and soil nitrogen availability during leaf litter decomposition in a Hawaiian Montane Forest" Ecosystems, 3: 484-494.

Hobbie, S. E. and P. M. Vitousek (2000). "Nutrient limitation of decomposition in Hawaiian forests" Ecology, 81: 1867-1877.

Hunt, H. W., E. R. Ingham, D. C. Coleman, E. T. Elliot and C. P. P. Reid (1988). "N limitation of production and decomposition in prairie, mountain meadow, and pine forest" Ecology, 69: 1009-1016.

Ito, M., M. J. Mitchell and C. T. Driscoll (2002). "Spatial patterns of precipitation quantity and chemistry and air temperature in the Adirondack region of New York" Atmos. Environ., 36: 1051-1062.

Keyser, P., T. K. Kirk and I. G. Zeikus (1978). "Lignolytic enzyme system of Phanerochaete chrysosporium: synthesized in the absence of lignin in response to nitrogen starvation" J. Bacteriol, 135: 790-7.

Knorr, M., S. D. Frey and P. S. Curtis (2005). "Nitrogen additions and litter decomposition: A meta analysis" Ecology, 86: 3252-3257.

Magill, A. H. and J. D. Aber. (1998). "Long-term effects of experimental N additions on foliar litter decay and humus formation in forest ecosystems" Plant Soil, 203: 301311.

Mann, L. K., D. W. Johnson, D. C. West, D. W. Cole, J. W. Hornbeck, C. W. Martin, H. Riekerk, C. T. Smith, W. T. Swank, L. M. Tritton and D. H. van Lear (1988). "Effects of whole-tree and stem-only clearcutting on postharvest hydrologic losses, nutrient capital and regrowth" For. Sci., 34: 412-428.

Marschner, B. and A. W. Wilczynski (1991). "The effect of liming on quantity and chemical composition of soil organic matter in a pine forest in Berlin, Germany" Plant Soil, 137: 229-236. 
McClaugherty, C. and B. Berg. (1987). "Cellulose, lignin, and N concentrations as rate regulating factors in late stages of forest litter decomposition" Pedobiologia, 30: $101-112$.

Miller, H. G., J. M. Cooper, J. D. Miller and O. J. L. Pauline (1979) "Nutrient cycles in pine and their adaptation to poor soils" Can Journal of Botany, 9: 19-26.

Nihlgard, B. (1985). "The ammonium hypothesis, an additional explanation to the forest dieback in Europe" Ambio, 14: 2-8.

O’Connell, A. M. (1988). "Nutrient Dynamics in decomposing litter in karri (Eucalyptus diversicolor F. Muell) forests of south western Australia" J. Ecol., 76: 1186-1203.

Olson, J. S. (1963). "Energy storage and the balance of producers and decomposers in ecological systems" Ecology, 44: 322-331.

Pastor, J., M. A. Stillwell and D. Tilman (1987). "Little blue stem litter dynamics in Minnesota old fields" Oecologia, 72: 327-330.

Peterjohn, W. M., M. B. Adams and F. S. Gilliam (1996). "Symptoms of nitrogen saturation in two central Appalachian hardwood forest ecosystems" Biogeochemistry, 35: $507-522$.

Piatek, K. B. and H. L. Allen (2001). "Are forest floors in mid-rotation stands of loblolly pine (Pinus taeda) a sink for nitrogen and phosphorus?" Can. J. For. Res., 31: 1164-1174.

Prescott, C. E. (1995). "Does N availability control rates of litter decomposition in forests?" Plant Soil, 168-169: 83-88.

Romkens, P. F., J. Bril and W. Salomons (1996). "Interactions between $\mathrm{Ca}^{2+}$ and dissolved carbon: implications for metal mobilization" Appl. Geochem., 11: 109-115.

Smith, C. T., M. L. J. McCormack, J. W. Hornbeck and C. W. Martin (1986). "Nutrient and biomass removals from a red spruce-balsam fir whole-tree harvest" Can. J. For. Res., 16: 381-388.

Stoddard, J. L. (1994). "Long-term changes in watershed retention of nitrogen: Its causes and consequences" In: Baker L. A. (Ed). Environmental Chemistry of Lakes and Reservoirs, Am. Chem. Soc., Washington DC.

Taussky, H. H. and E. Shorr (1953). "A microcolorimetric method for the determination of inorganic phosphorus" J. Biol. Chem., 202: 675-685.

Vitousek, P. M., J. D. Aber, R. W. Howarth, G. E. Likens, P. A. Matson, D. W. Schindler, W. H. Schlesinger and D. G. Tilman (1997). "Human alteration of the global nitrogen cycle: sources and consequences" Ecol. Applic., 7: 737-750. 